\title{
A Preliminary Archaeological Survey for the Conquista Project In Gonzalez, Atascosa, and Live Oak Counties, Texas
}

A. Joachim McGraw

Follow this and additional works at: https://scholarworks.sfasu.edu/ita

Part of the American Material Culture Commons, Archaeological Anthropology Commons, Environmental Studies Commons, Other American Studies Commons, Other Arts and Humanities Commons, Other History of Art, Architecture, and Archaeology Commons, and the United States History Commons

Tell us how this article helped you.

This Article is brought to you for free and open access by the Center for Regional Heritage Research at SFA ScholarWorks. It has been accepted for inclusion in Index of Texas Archaeology: Open Access Gray Literature from the Lone Star State by an authorized editor of SFA ScholarWorks. For more information, please contact cdsscholarworks@sfasu.edu. 
A Preliminary Archaeological Survey for the Conquista Project In Gonzalez, Atascosa, and Live Oak Counties, Texas

\section{Creative Commons License}

\section{(c) (1) (8)}

This work is licensed under a Creative Commons Attribution-NonCommercial 4.0 International License 


\section{A Preliminary \\ Archaeological Survey for the CONQUISTR PRQJEET In Gonzales, htascosa, and bive Dak Counties, Texas}

A. JOACHIM McGRAW

Center for Archaeological Research The University of Texas-at San-Antonio Archaeological Survey Report, No. 76

1979 
A PRELIMINARY ARCHAEOLOGICAL SURVEY FOR THE CONQUISTA PROJECT IN GONZALES, ATASCOSA AND LIVE OAK COUNTIES, TEXAS

\author{
A. Joachim McGraw
}

Center for Archaeological Research The University of Texas at San Antonio Archaeological Survey Report, No. 76 
TABLE OF CONTENTS

Page

List of figures. ..................... $i_{i}$ Acknowledgments. .................... $i$... . . Introduction . . . . . . . . . . . . . . . . . 1 Previous Research...................... 3 Environment. .................... 3 Chronology of Prehistoric Habitation ................. 4 Site Descriptions. .................... 7 Artifact Descriptions. . . . . . . . . . . . . . . 20 Concluding Comments and Recommendations. . . . . . . . . . . . . 24 References cited .................. 27 


\section{LIST OF FIGURES}

Figure

1. Map of Conquista Survey Areas in Gonzales, Atascosa and Live Oak Counties. . . . . . . . . . . . . . . . . . 2

2. Research Design, Conquista Survey ............. 5

3. Research Design, Preliminary Site Description Methodology . . . . . 6

4. Map of the Jacobs Property, Gonzales County . . . . . . . . . 9

5. Map of the Smith-Stridde Properties, Live Oak County. . . . . . . 15

6. Hearth Feature at 41 LK $226 \ldots$. . . . . . . . . . . . 16

7. Map of the Tom Retzloff Property, Atascosa County . . . . . . . 18

8. Conquista Survey Artifacts. . . . . . . . . . . . . . 22

9. Conquista Survey Artifact . . . . . . . . . . . . . . . 25 


\section{ACKNOWLEDGMENTS}

The author would like to express his thanks to all those whose cooperation made this report possible, especially Mr. Morris Merritt and Mr. Charles Salsman of the Conquista Project, Mr. Herb Uecker of the Center for Archaeological Research, and last but not least, Mr. John Twedel1. The project was carried out under the general supervision of Dr. Thomas R. Hester, Director, Center for Archaeological Research, The University of Texas at San Antonio, and the author thanks Dr. Hester for his suggestions and comments throughout the project. 


\section{INTRODUCTION}

During late February and early March 1979, an archaeological and historical survey of the Jacobs, Tom Retzloff and Smith-Stridde properties in Gonzales, Atascosa and Live Oak Counties was conducted. These properties are leased by the Continental 0il Company. The purpose of the survey was to evaluate the archaeological and historic potential of these properties before the leases are extensively modified by proposed uranium mining operations. The survey was conducted under the terms of a contract between Continental $0 i 1$ Company's Project, as represented by Mr. Morris Merritt and Mr. Charles Salsman, and Dr. Thomas R. Hester, Director, Center for Archaeological Research, The University of Texas at San Antonio.

The field survey was conducted by A. Joachim McGraw and Herb Uecker, Technical Staff Assistants of the Center, and under the general supervision of Dr. Hester. A detailed examination of artifacts collected during the survey was initiated following field operations.

Four separate areas were surveyed during field investigations (see Fig. 1): the Jacobs property in southeastern Gonzales County; the adjacent Smith and Stridde properties in northern Live Oak County; and the Tom Retzloff property in eastern Atascosa County. Each locality was specifically identified on USGS 1:24,000 scale topographic maps. At each location, the survey consisted of a series of transects that encompassed both upland and lowland areas. For convenience in the field, the study areas were often divided into quadrants determined by distinctive topographic features such as drainages, high upland areas, etc. These quadrants were then transected individually to insure more complete survey coverage and for better field control, especially in areas of dense brush where map correlations were difficult. Research methodology generally followed the guidelines presented in Hester, Heizer and Graham (1975). Site designations were determined by the type and amount of artifactual materials on the surface, and collection of materials during the survey was limited to diagnostic or otherwise significant artifacts. Representative random judgment samples (Redman 1974; McGraw and Valdez 1978) were collected from sites where large quantities of lithic debitage were exposed. Special surface collections were made at these sites to enhance the perspective of prehistoric lithic characteristics in the study area. Elevations and distances of sites to water sources and other natural resources were also important considerations in site descriptions. Data on the newly discovered sites were recorded on standard site survey forms used by the Center for Archaeological Research, and all collected materials were placed in paper or plastic bags and labeled as to site number, date, type of collection, name of collector and other pertinent site information. Several soil samples were taken at selected site locations when washes or other erosional features revealed buried deposits. These samples were taken primarily to (1) objectively distinguish soil zone colors using a Munsell color chart and (2) to identify other basic soil characteristics and associations through later laboratory research.

Due to the widely distributed property areas across three counties of south Texas, a general research design was initiated prior to field survey operations to maximize data gathering efforts. The surveys were directed not only toward individual site identifications but also toward a description of the macro- 


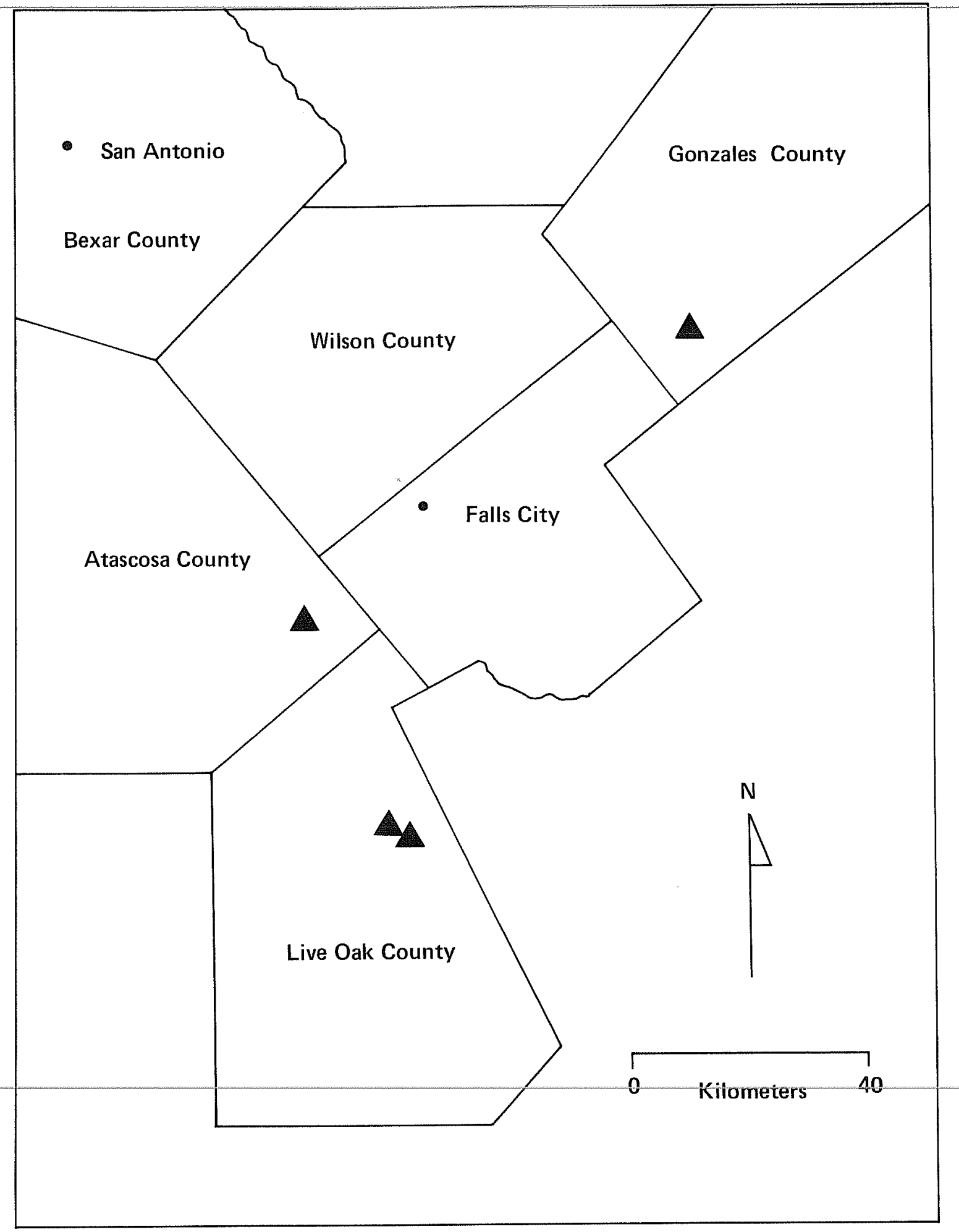

Figure 1. Map of Conquista Survey Areas in Gonzales, Atascosa and Live oak Counties. 
environmental conditions in which the sites were located. Combined with background ethnographic and historical research, the research methodology was directed toward a preliminary description of intersite relationships and, if possible, toward an areal distribution of various prehistoric technological processes as reflected from the archaeological record on the surface (see Figs. $2,3)$. This concept of not only identifying sites but also viewing them within the perspective of cultural and environmental relationships was considered to more accurately reflect the character and importance of each archaeological site.

\section{PREVIOUS RESEARCH}

The archaeology of south Texas and of the physiographic transition area between coastal and central Texas is still poorly understood. Many of the known sites in the region have been recorded by amateurs, and much of this information is at a basic data-gathering stage. Reports that deal with the study area and surrounding counties include Wilson (1930), Johnson, Suhm and Tunnel1 (1962) Nunley (1963), Hsu and Ralph (1968), Crawford (1971) and Fox et al. (1978). The Department of Highways and Public Transportation has recently completed field excavations at the major Archaic burial site of 41 LK 28 in Live Oak County, and the Center for Archaeological Research is presently investigating an extensive series of archaeological sites in the proposed Choke Canyon Reservoir near Three Rivers, also in Live Oak County.

In addition to past site specific research orientations, Hester and others have published a number of papers focusing on the documentation of various artifact forms from south Texas (Hester 1968a,b,c; 1970a,b; 1972a,b; 1975a; 1976; Hester and Hi11 1971; Hester and Rodgers 1971; Hester et al. 1975; Hill and Hester 1971; Hi11, House and Hester 1972; Shafer and Hester 1971). Surface collections and limited test excavations from several sites have also been documented (Hester 1969; Hester 1971; 1972c; Hester and Ruecking 1969; Hester, White and White 1969; Nunley and Hester 1966). These publications have documented projectile point types and tool forms in the region and have presented several settlement and subsistence pattern hypotheses.

Three other publications also deal with the cultural resources near Live Oak and Atascosa Counties. Wakefield (1968) performed a preliminary inspection of the Choke Canyon Reservoir and Mallouf (1975) recorded nine prehistoric sites during a survey in the Tipps Park area near Three Rivers. Shafer and Baxter (1975) have also conducted an archaeological survey along portions of San

Miguel Creek and tributaries of the Atascosa River in Atascosa and McMullen Counties.

\section{ENV IRONMENT}

The environment of south Texas generally and of Live Oak and Gonzales Counties specifically has been discussed in some detail in Lynn, Fox and 0'Malley (1977), Fox et al. (1974) and creel et al. (1979). This report will briefly examine the more relevant environmental aspects and their relationships to the archaeological record. For further information on various aspects of the environment 
of south Texas the reader is referred to Anders and Baker (1961), Blair (1950, 1952) and Byrd (1971).

The environmental characteristics of the present study locations in Gonzales, Live Oak and Atascosa Counties are reflective of the physiographic transition zone between coastal and central Texas. Topography for most of the area is rolling to moderately hilly, although some areas are nearly flat. Altitude above mean sea level ranges from $\mathrm{ca} .460$ feet in western upland localities to ca. 90 feet above msl nearer the Gulf (Anders and Baker 1961). Several major drainage systems flow southeastward through these three counties: the Guadalupe River drainage and its tributaries in Gonzales County and the Nueces River drainage in Atascosa and Live Oak Counties.

The low topographic relief throughout much of the three-county area is composed of residual soils which have developed along southeasterly dipping sedimentary geologic strata of Tertiary age (U.S. Department of the Interior 1975:B-8). Major geologic strata which outcrop in the study area include the Jackson group or Fayette Formation (Eocene), the Frio Formation (01igocene) and the Catahoula Formation (Miocene). Materials found in these strata generally consist of siltstone, tuff, shale, tuffaceous sandstone and betonitic clay stone, and shaly sandstone in strata which normally dips at rates of 80-120 feet per mile southeastward. Other geologic units also include Quaternary stream and terrace deposits of clay with varying amounts of sandy gravels and recent alluvium (Lynn, Fox and O'Malley 1977).

Blair (1950) defines the flora and fauna of south Texas as belonging to the Tamaulipan biotic province. The area is characterized as a mesquite and desertgrass savannah with uplands populated by thorn brush and mesquite, native grasses and prickly pear, while drainages are often dominated by mesquite. Riparian zones are often composed of elm, hackberry, pecans, ash and oak. Wildlife species in the general area include white-tailed deer, javelina, wild turkey, quail, mourning dove, scaled quail, white-winged dove, armadillo, coyote, fox, squirrel, cottontail and jackrabbit, raccoon and a variety of reptiles and fish. For a more detailed explanation of flora and fauna, see also Blair (1950, 1952) and Lynn, Fox and 0'Malley (1977). Climatological data for the region, which can briefly be defined as semi-arid with prevailing southeasterly winds, is presented in Anders and Baker (1961) and creel et al. (1979)

\section{CHRONOLOGY OF PREHISTORIC HABITATION}

The cultural chronology of south Texas falls into four distinct periods of prehistory: the Paleo-Indian, the Archaic, the Late Prehistoric and the Historic periods. The Paleo-Indian state, as outlined by Suhm (1960), occurred ca. 9200-6000 B.C. and includes the earliest evidences of man in North America. Associated with a big-game hunting and gathering subsistence pattern, PaleoIndian projectile points in south Texas are commonly represented by clovis, Folsom, Plainview, Golondrina and Angostura dart points. The Archaic is represented by archaeological materials that range in age from ca. 5000 B.C. to A.D. 1000. Archaeological evidence suggests this widespread cultural pattern was characterized by a more diversified smaller game hunting and gathering subsistence. It is assumed that due to enviroclimatic changes at the end of the 


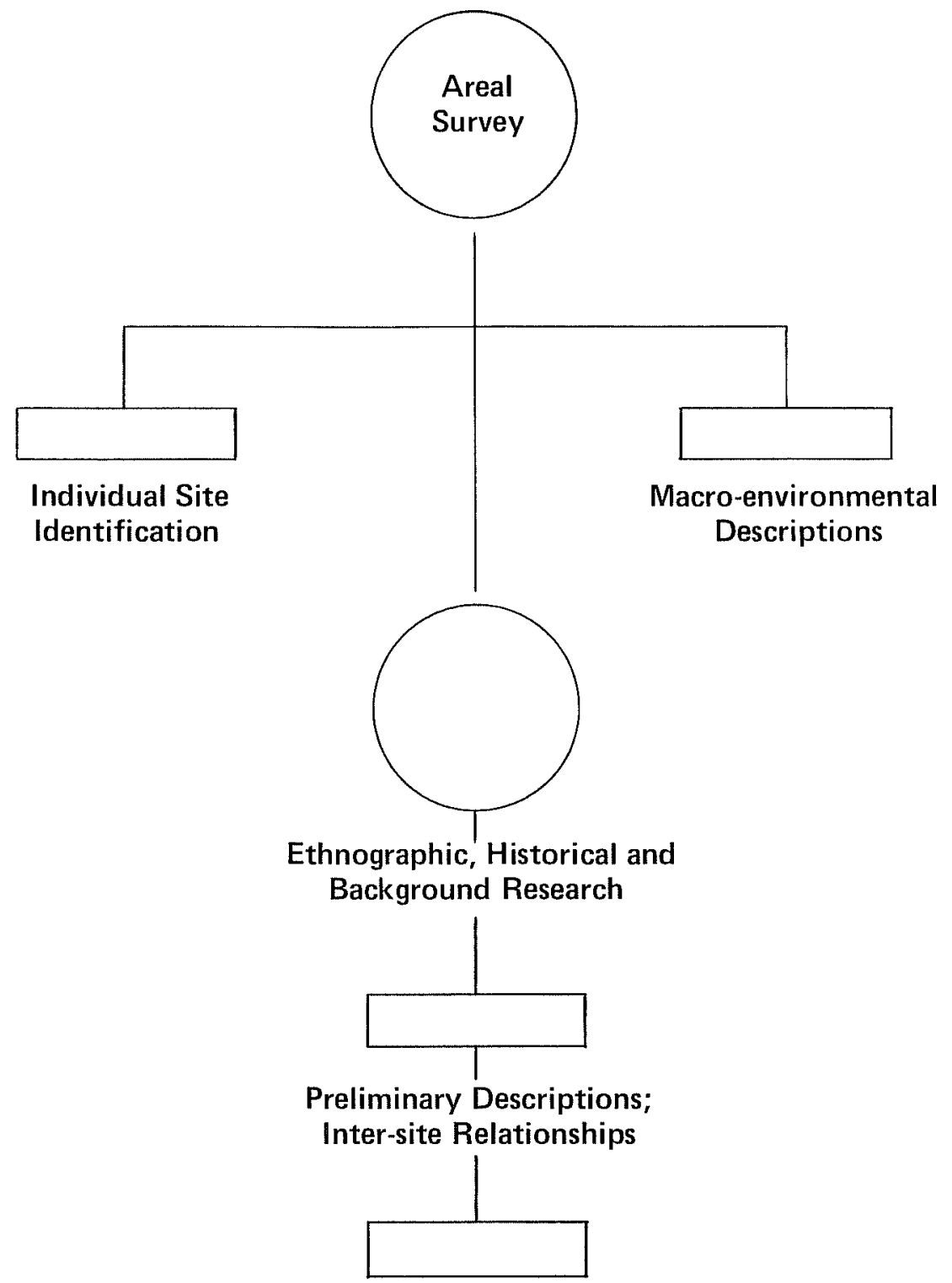

Areal Distributions of Technological Processes

Figure 2. Research Design, Conquista Survey. 


\section{Areal Survey}
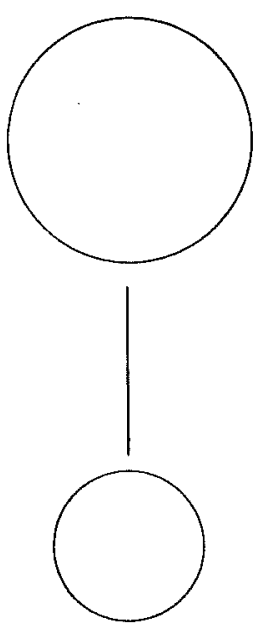

Site Identification


Horizontal,

Vertical

Extent \&

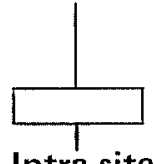

Flora/Fauna

Distribution

Intra-site

Activity

Areas

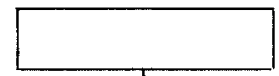

Topography

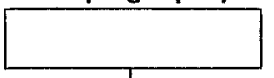

Natural Resources
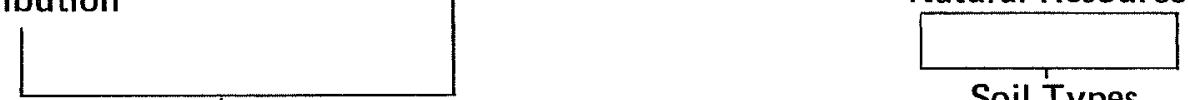

Soil Types

Comparison with

Ethnographic \& Historic Data

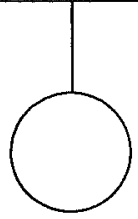

Preliminary Site Description

Figure 3. Research Design, Preliminary Site Description Nethodology. 
Pleistocene, emphasis on hunting shifted away from the large game animals of the earlier period to smaller animals such as deer and modern species of bison. Divided into Early, Middle and Late subperiods, the Archaic occupations throughout Texas are represented by an abundance of lithic artifacts and a wide variety of dart point types and other bifacially worked tools. It should be noted that Hester (1975) has suggested a Pre-Archaic period (ca. 6000-3500 B.C.) which occurred as a transitional phase between the Paleo-Indian and Archaic stages.

The Late Prehistoric period (after A.D. 1000) was characterized by bonetempered ceramics and new, distinctive lithic forms based on the introduction of the bow and arrow. The Historic period of south Texas archaeology is represented by intrusions of Plains Indians such as the Apache and Comanche and the arrival of Anglo European settlers. For more detalled discussions of these periods and their related cultural sequences, the reader is referred to Campbell (1960), Suhm and Jelks (1962), Suhm (1960), Hester (1975, 1976) and Hester and Hill (1975).

\section{SITE DESCRIPTIONS}

A total of 18 prehistoric sites were discovered during the survey: 11 on the Jacobs property (41 GZ 160-170), one on the Smith 1ease (41 LK 226), one on the Stridde property (41 LK 227) and five on the Retzloff property (41 AT 58-62). Based on preliminary field examination and subsequent laboratory analysis, two of these sites, $41 \mathrm{GZ} 162$ and 41 LK 226, are recommended for further work in the form of testing and limited excavation operations to determine eligibility to the National Register of Historic Places.

Site descriptions in this section maintain the format listed below, using the data recorded on standard site survey forms. Site numbers were given arbitrarily in order of discovery, and consecutively numbered sites may, but do not necessarily, imply cultural relationships.

For convenience, this section will discuss the archaeology of each property area separately, and each site description will follow the standardized format briefly defined below (cf. McGraw, Valdez and Cox 1977):

Location: Describes the site as viewed from a general geographic and environmental context and in relation to known geographic features.

Elevation: Refers to elevation above mean sea level as identified on USGS topographic maps. Elevations are described in feet to correspond with project maps.

Description: Brief, specific statements concerning archaeological evidence, depth, extent and condition.

Type of site: 0ccupational (campsite), quarry, workshop, temporary occupation, multi-functional, etc.; the latter refers to a site reflecting a number of distinct activities. 
Environmental characteristics: Brief geographic and environmental descriptions of the site.

Distances from water source: Refers to horizontal and vertical estimations.

Interpretation/Remarks: A statement on the extent, importance and condition of the site; this will include recommendations, if any, for further work.

Results of the Archaeological Survey at the Jacobs Property (Fig 4)

Site 41 GZ 160

Location: Along eastern fence line property area, 0.3 kilometers south of the intersection of the northern fence line and the entry road (see Fig. 4).

Elevation: Maximum 315 feet, minimum 300 feet above ms l.

Description: An oval 1ithic scatter ca. 150 meters north-south and 80 meters east-west. Materials observed include a light to moderate scatter of chipped stone often less than $3 \mathrm{~cm}$ in individual length. Lithic debris was often firereddened secondary and tertiary flakes of chert, quartzite or chalcedony.

Type of site: Light to moderate lithic scatter.

Environmental characteristics: The site is located in an upland area in a cleared pasture and may extend eastward beyond the Jacobs property. Short grasses predominate the local vegetation.

Distance from water source: Horizontal 1.5 to 1.7 kilometers, vertical ca. 16.5 meters.

Interpretation/Remarks: The light to moderate lithic scatter has been damaged in the past by land-clearing and perhaps plowing. No further work is recommended.

Site $41 \mathrm{GZ} 161$

Location: On the east bank of Rocky Creek and just south of the intersection of the creek and an unimproved dirt road in the northeastern margins of the Jacobs property.

Elevation: Maximum 270 feet, minimum 260 feet above ms 1 .

Description: A sma 11, light lithic scatter ca. 25 meters in diameter. Site appears heavily damaged by erosion.

Type of site: Light 1ithic scatter.

Environmental characteristics: The site appears to be located on the southern bank and upper stream terrace where erosion has exposed small chert, chalcedony and quartzite pebbles. Vegetation includes mesquite and hackberry. 
This page has been

redacted because it

contains restricted

information. 
Distance from water source: Horizontal ca. 10 meters, vertical 2 meters.

Interpretation/Remarks: No further work.

Site 41 GZ 162

Location: Located on the east bank and just north of the confluence of Rocky Creek with its major southeasterly flowing tributary.

Elevation: Maximum 270 feet, minimum 260 feet above ms 7.

Description: Site appears to be an extensive multi-functional activity area with at least two distinct cultural components as reflected in the collection of two Angostura dart point fragments and several other distinctive but chronologically undiagnostic biface fragments. Fire-reddened rock occurs throughout the area, which covers ca. $200-250 \mathrm{~m}^{2}$.

Type of site: Multi-functional; occupational, lithic workshop.

Environmental characteristics: The site is located on a knoll that rises above the upper terraces (eastern bank) of Rocky Creek and its junction with a southeasterly flowing tributary. Vegetation is primarily short grasses, thorn brush and mesquite.

Distance from water source: Horizontal ca. 15-20 meters, vertical 2-3 meters.

Interpretation/Remarks: Site $41 \mathrm{GZ} 162$ appears to be an extensive area of multi-functional, prehistoric activity. The collection of two Angostura biface fragments implies Paleo-Indian period activity and, should these materials be associated with buried cultural deposits, the site could be of National Register quality. This report recommends limited hand-testing and selective backhoe trenching to determine the significance of the surficial materials.

Site $41 \mathrm{GZ} 163$

Location: Located ca. 0.25 kilometers east of $41 \mathrm{GZ} 162$ on the north bank of a southeasterly flowing tributary of Rocky Creek.

Elevation: Maximum 260 feet, minimum 255 feet above ms 1.

Description: A light to moderately occupied multi-functional activity site with evidences of fire-reddened sandstone rocks. Total site area is ca. $100 \mathrm{~m}^{2}$. Locality appears to have been cleared in the past. No finished tools or diagnostic artifacts were noted.

Type of site: Multi-functional.

Environmental characteristics: Located on upper terraces of intermittent drainage. Vegetation includes much mesquite, elm and tall grasses. 
Distance from water source: Horizontal 30 meters, vertical 3 meters.

Interpretation/Remarks: No further work.

Site 41 GZ 164

Location: 0.2 kilometers south of where the tributary (intermittent) drainage of Rocky Creek intersects a section of the Jacobs property entry road, near the southeast portions of the lease.

Elevation: Maximum 290 feet, minimum 270 feet above ms 1.

Description: The ca. $75 \mathrm{~m}^{2}$ is a light fithic scatter along the slopes of a hill. The site is located in a cleared pasture and is extensively damaged by modern alterations.

Type of site: Light lithic scatter.

Environmental characteristics: The site is located on the slopes of a large hill just south of an intermittent drainage. Vegetation consists of low grasses and some prickly pear.

Distance from water source: Horizontal 0.2 kilometers, vertical ca. 2 meters. Interpretation/Remarks: No further work.

Site 41 GZ 165

Location: Ca. 200 meters north of the intersection of the entry road and Rocky Creek. A light scattering of lithic debris was noted along the upland margins that parallel the drainage westward for 175 meters.

Elevation: Maximum 310 feet, minimum 300 feet above ms 1 .

Description: The site is a light lithic scatter along the upland margins paralleling the creek and appears extensively damaged by past land-clearing efforts.

Type of site: Light lithic scatter.

Environmental characteristics: The site is located on a high upland ridge complex adjacent to a flowing drainage. Vegetation generally consists of tall grasses interspersed with occasional stands of mesquite or oak.

Distance from water source: Horizontal 0.2 to 0.4 kilometers, vertical 18 to 19 meters.

Interpretation/Remarks: No further work. 
Site $41 \mathrm{GZ} 166$

Location: Across the drainage and ca. 75 meters west of site 41 GZ 162.

Elevation: Maximum 290 feet, minimum 260 feet above ms 1.

Description: Site 41 GZ 166 appears to be a once extensive multi-functional activity area ca. $250 \mathrm{~m}^{2}$ now almost totally destroyed by modern land alterations. Lithic debris concentrations eroding from sandy stream banks appear to be redepositions from materials bulldozed from higher elevations.

Type of site: Fire-reddened rocks, modified tertiary flakes and lithic debris suggest multi-functional activities.

Environmental characteristics: The site is located along the slopes of an extensive ridge complex just north of Rocky Creek's confluence with an intermittent tributary. Vegetation consists of low grasses and oak.

Distance from water source: Horizontal 8 meters, vertical (maximum) 16 meters.

Interpretation/Remarks: Cultural materials may be related to site $41 \mathrm{GZ} 162$ but no diagnostic artifacts were recovered. No further work is recommended.

\section{Site 41 GZ 167}

Location: Atop a high knoll in the center of the study area and bounded on the east and west by intermittent drainages.

Elevation: Maximum 290 feet, minimum 270 feet above ms 1.

Description: A small, multi-functional activity area characterized by firereddened rocks, Tithic debris and possible tool fragments.

Type of site: Multi-functional.

Environmental characteristics: Located on a high knoll between intermittent tributaries of Rocky Creek. Vegetation consists of tall grasses and a grove of oaks.

Distance from-water-source: Horizontal 20-meters, vertical-ca. 78 meters.

Interpretation/Remarks: No further work recommended due to the light distribution of cultural materials and the lack of diagnostic artifacts.

\section{Site $41 \mathrm{GZ} 168$}

Location: Located in the southwestern margins of the property just south of the intermittent tributary and following the contours of the 300 feet USGS contour line as noted on 1:24,000 scale topographic map. 
Elevation: Maximum 310 feet, minimum 300 feet above ms 1 .

Description: A linear, lithic scatter lightly scattered for ca. 400 meters along the margins of a ridge complex and adjacent to an intermittent drainage. Small concentrations of chipped stone were occasionally noted in this area, but no bifaces or other finished tools were noted.

Type of site: Light lithic scatter.

Environmental characteristics: An upland ridge complex adjacent to an intermittent drainage. Vegetation varies from dense stands of oaks to cleared pasture area.

Distance from water source: Horizontal 40 meters, vertical 2 meters.

Interpretation/Remarks: No further work.

Site 41 GZ 169

Location: In the southwest corner of the Jacobs property just north of where the intermittent drainage intersects the western fence line.

Elevation: Maximum 330 feet, minimum 300 feet above ms 1 .

Description: A small occupational and multi-functional prehistoric activity area characterized by chipped stone, chert cobbles, fire-reddened rocks and modified flakes. Activity area is ca. $80 \mathrm{~m}^{2}$.

Type of site: Multi-functional.

Environmental characteristics: The site is located in the upland portion of the study area near a smal7, intermittent tributary. Vegetation in the area consists of short grasses, mesquite and prickly pear.

Distance from water source: Horizontal 10 meters, vertical 2 meters.

Interpretation/Remarks: The lack of finished artifacts and the small site area suggest no further work is necessary at this site.

Site 41 GZ 170

Location: The linear site outline generally follows the 300 foot contour line in the southwestern portion of the study area, as identified on $1: 24,000$ scale maps. Length of the light lithic scatter may exceed 400 meters. The scatter generally follows the contours of the ridge complex northwest of a small intermittent tributary.

Elevation: Maximum 320 feet, minimum 290 feet above ms 1. 
Description: The site appears heavily damaged by erosion and modern land clearing. No concentrations or diagnostic artifacts were noted throughout this large area.

Type of site: Light lithic scatter.

Environmental characteristics: The site is located on the slopes of an extensive ridge complex adjacent to an intermittent drainage. Vegetation consists of short grasses, mesquite and prickly pear.

Distance from water source: Horizontal 200-300 meters, vertical 6-7 meters.

Interpretation/Remarks: No further work.

Results of the Archaeological Survey at the Smith and Stridde Properties

Major portions of both these areas have been extensively disturbed by past mining operations or land clearing for agricultural usage. Only one archaeological site was noted at each of these adjacent lease areas (see Fig. 5).

Site $41 L K 226$

Location: Ca. 0.4 kilometers southeastward from the northwest corner of the Smith property. The site is distinguished by a buried hearth exposed in an eroding gully wash at the edge of a large cleared pasture area.

Elevation: 290 feet above ms 1 .

Description: Gully erosion has uncovered a thin layer of fire-reddened sandstone rocks buried ca. $26 \mathrm{~cm}$ below the surface. The layer of tuffaceous sandstone materials was distributed horizontally $\mathrm{ca} .100 \mathrm{~cm}$ and appeared to rest atop a compacted, clayey, light-brown, sub-angularly grained soil zone. In close association with the hearth and eroding from the gully at a depth of $12 \mathrm{~cm}$ was a fire-reddened tertiary chert flake. No other cultural materials or diagnostic artifacts were noted at or near the feature.

Type of site: Occupation.

Environmental characteristics: The site is located in an erosional cut at the edge of a large cleared pasture area. South of the site, dense brush predominates. The area is located on the margins of an upland ridge.

Distance from water source: Horizontal ca. 300 meters, vertical 6-7 meters. Interpretation/Remarks: Limited testing is recommended to determine the subsurface extent and cultural associations. 


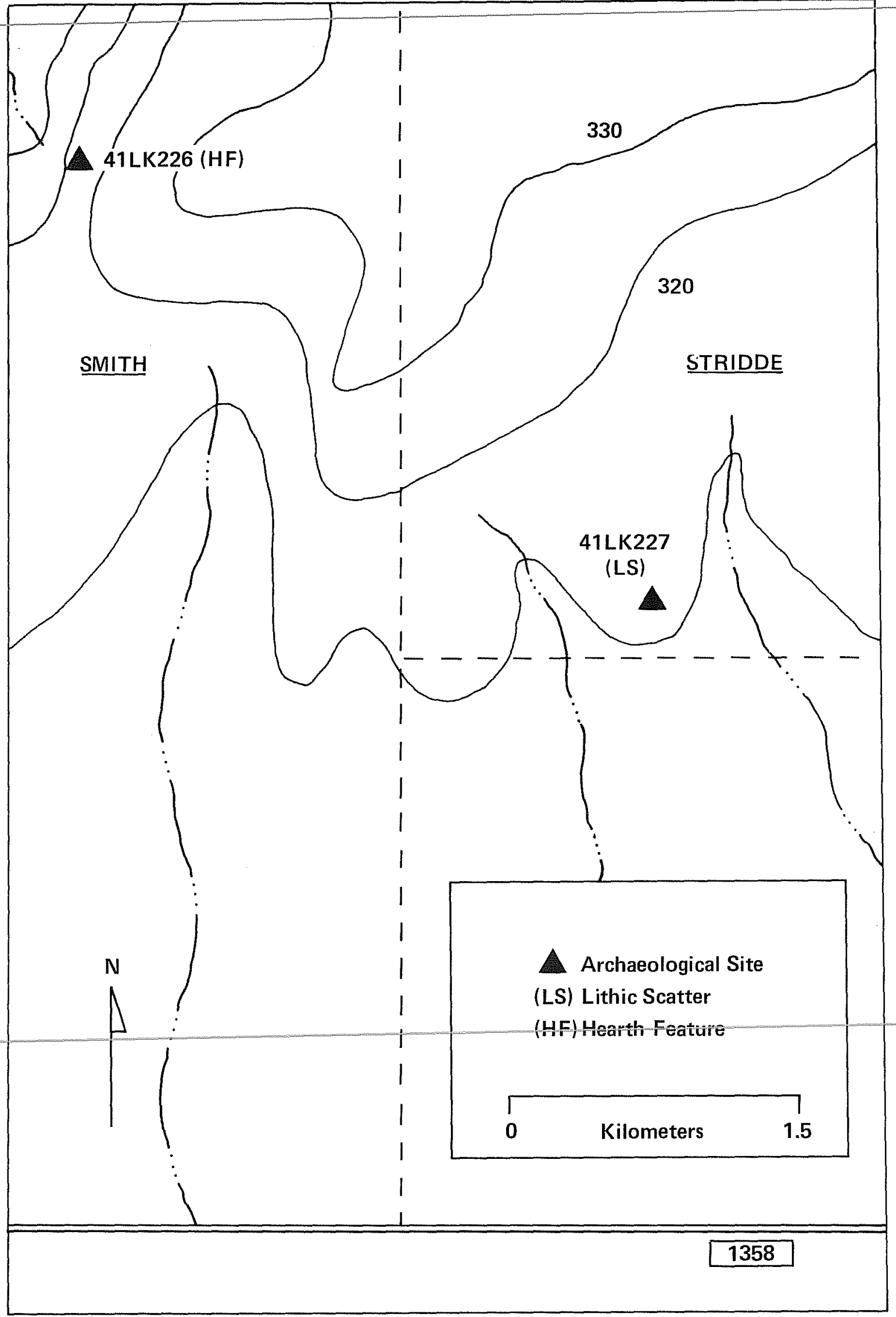

Figure 5. Map of the Smith-Stridde Properties, Live Oak County. Elevations are in feet to correspond with USGS maps. 

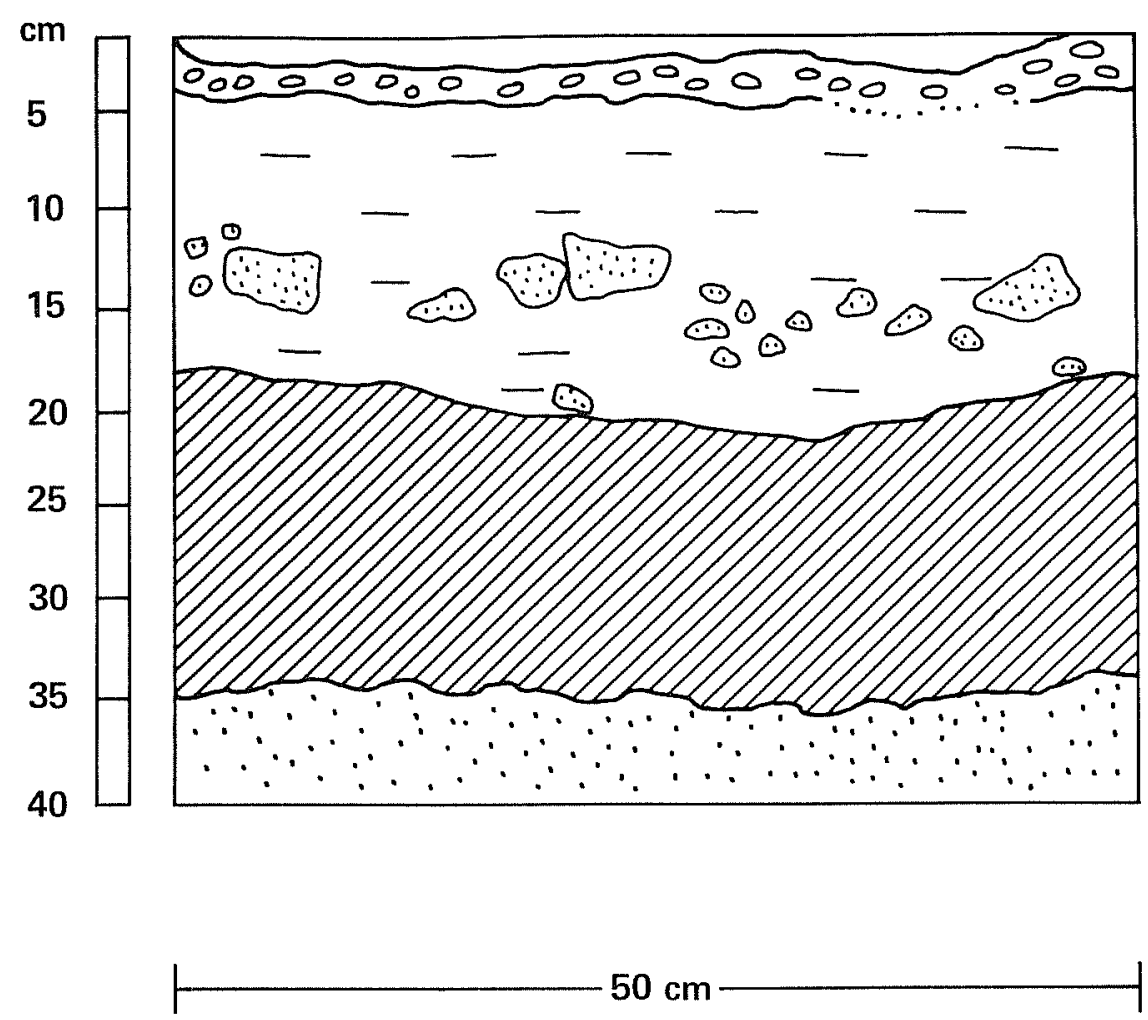

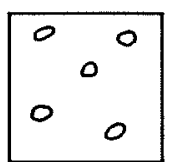

Surface Fill; 10YR3/4

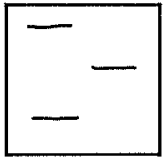

Sandy Loam: 10YR3/6

Dark yellowish brown

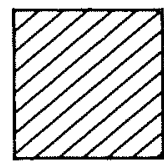

Clayey Transition;

10YR7/8

Yellow Clay

$\because \because \because \because$

Compacted Clavev

Materials; 10YR8/8

Yellow Clay

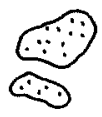

Sandstone Hearth Feature

Figure 6. Hearth Feature at 41 LK 226. View toward northwest. 
Site 41 LK 227

Location: Along the southern fence line of the Stridde property on a smal1 knol1 between two southward flowing but intermittent drainages (see Fig. 5).

Elevation: 300 feet above ms 1 .

Description: The site is composed of a small lithic scatter of chipped stone materials distributed atop a small knoll. Total site area was identified as less than $50 \mathrm{~m}^{2}$ and no finished tools or diagnostic artifacts were recovered.

Type of site: Light lithic scatter.

Environmental characteristics: A small knoll situated between two intermittent drainages with extremely dense brush in the surrounding areas.

Distance from water source: Horizontal 10-50 meters, vertical ca. 3-4 meters. Interpretation/Remarks: No further work.

Results of the Archaeological Survey in the Tom Retzlof6 Property

Five prehistoric sites were recorded on the Tom Retzloff property; their locations are illustrated in Fig. 7. Four of the sites were defined as light to moderate lithic scatters, the largest of these being 41 AT 62 . Site 41 AT 61 was described as a small occupation site based on the scattering of firereddened sandstone rocks. Although a large sandstone metate was recovered at 41 AT 61, the general 1ack of other artifactual materials combined with other surface features indicates extensive areal disturbance, and no further work is recommended at any of these sites. Detailed descriptions of individual sites are presented below.

\section{Site 41 AT 58}

Location: Located on the upper margins of a ridge complex between two intermittent drainages in the southeastern portion of the study area. The site is located on and near an unmarked, unimproved road that leads to a modern deer b7ind, also on the site.

\section{Elevation: 400 feet above ms 1 .}

Description: The site is a light to moderate lithic scatter ca. $75 \mathrm{~m}^{2}$ along the upper margins of a densely brushed ridge complex.

Type of site: Light lithic scatter.

Environmental characteristics: Dense vegetation in the form of mesquite and other thorn brush covers the site area. Nearby drainages are intermittent.

Distance from water source: Horizontal ca. 175 meters, vertical 2-3 meters. 
This page has been

redacted because it

contains restricted

information. 
Interpretation/Remarks: No further work.

Site 41 AT 59

Location: Located in the extreme southwest corner of the property along an upland ridge identified on USGS topographic maps at the 400 foot contour line.

Elevation: Maximum 410 feet, minimum 400 feet above ms 7 .

Description: The site is a light lithic scatter ca. $100 \mathrm{~m}^{2}$ in an upland location. No finished or diagnostic artifacts were noted in this area.

Type of site: Light Tithic scatter.

Environmental characteristics: The locality is overgrown with dense thorn brush and mesquite. 47 AT 59 is located on an upland ridge complex.

Distance from water source: No water resources were noted within a 400 meter radius.

Interpretation/Remarks: No further work.

Site 41 AT 60

Location: Located in a pasture area just north of a fence line running northeast in the southern portion of the study area (see Fig. 7).

Elevation: 410 feet above $\mathrm{ms}$.

Description: The site appears to be a heavily disturbed area reflecting light to moderate lithic workshop activities. The locality is presently a pasture area with prior land clearing.

Type of site: Light to moderate lithic scatter ca. $100 \mathrm{~m}^{2}$.

Environmental characteristics: The site is located along an upland ridge system in a cleared pasture area. Directiy south lies dense brush but no evidence of cultural materials was present in the latter area.

Distance from water source: No water resources noted within 400 meters.

Interpretation/Remarks: No further work.

Site 41 AT 61

Location: 0.5 kilometers due northeast and along the fence line from 41 AT 60 . Elevation: 410 feet above ms 1 . 
Description: This is a small occupation site ca. $75 \mathrm{~m}^{2}$ in diameter. Firefractured and reddened sandstone fragments, several pieces of chipped stone and a sandstone metate $(40 \times 35 \times 10 \mathrm{~cm})$ were observed at the site. No other features or material concentrations were noted at the site. The site appears extensively damaged by former clearing for agricultural usage.

Type of site: Small occupation.

Environmental characteristics: Similar to 41 AT 60 .

Distance from water source: None noted within 300 meters.

Interpretation/Remarks: No further work.

Site 41 AT 62

Location: Located in the extreme west corner of the Retzloff lease 0.4 kilometers south of FM 1099 and just north of the intermittent drainage as identified on USGS maps (see also Fig. 7).

Elevation: Maximum 390 feet, minimum 370 feet above ms 1 .

Description: A light lithic scatter was noted in a cleared and terraced field currently being used as a pasture. The materials of chipped stone appear to be extensively disturbed, and the site as a whole appears to have been almost tota11y destroyed by modern land-clearing efforts. Site dimensions are ca. $250 \mathrm{~m}^{2}$.

Type of site: Light lithic scatter.

Environmental characteristics: Located on a broad terrace due north of an intermittent drainage. Vegetation consists of short grasses.

Distance from water source: Horizontal 30-150 meters, vertical ca. 6 meters maximum.

Interpretation/Remarks: No further work.

Artifacts from the Conquista survey were collected from the surface on the basis of diagnostic potential and are representative of the types of materials occurring on the surface of the sites. Cultural materials were limited to lithic artifacts; these were later separated into morphological categories such as lithic debitage (flakes, cores, utilized debris, etc.) and finished tools (projectile points, bifaces and unifaces). A brief definition of these categories will precede a description of diagnostic or selected artifacts from the Conquista survey (see Figs. 8,9). 
For the purposes of this study, many artifact and debris categories are defined on the degree and type of retouch; this refers to the detachment of small flakes from a point or tool for the purposes of resharpening, alteration of the edge, or strengthening. The result of this action is flake scars on dorsal ends and sides of the worked material. This report will briefly divide the materials into two groups: (1) cores and lithic debris and (2) unifacial and bifacial artifacts.

\section{Cores and Lithic Debris}

Cores are the raw materials in the form of siliceous stone for various types of lithic reduction processes. They often exhibit one or more scars where pieces (flakes) have been detached. Cores occasionally exhibit marginal retouch modification or wear (utilization) along portions of their surfaces.

Debris in the form of small pieces or flakes detached from the core often reflects the extent or stage of the 1ithic process and the particular technique involved. By examination of various attributes, a single piece of debris can often be associated with one of a series of sequential tool manufacturing processes. Flakes observed during field survey operations were divided into three types based on the absence or presence and degree of exterior (cortex) surface: primary flakes with cortex on their dorsal surfaces; secondary flakes, with some cortex; and interior or tertiary flakes, with no cortex or dorsal surfaces.

Throughout the surveyed areas, cores and core fragments were noted in relative scarcity to other materials. Between 3-8 cm in length, these cores reflected polyhedral flake detachments or were identified as roughly ovate cores with multi-directional flake scars.

Scattered throughout the sites, the flakes associated with the former materials suggest workshop activities. The high incidence of secondary and decortification flakes at these localities can be contrasted to the types of flakes noted at occupation sites (interior flakes, thinning, utilized or retouched flakes; see also Hester 1975a).

\section{Unifacial and Bifacial Artifacts}

These artifacts reflect retouch and/or utilization on dorsal and/or ventral surfaces and may be grouped into such categories as scrapers, gouge-like tools and projectile points. Collected materials are presently on file at The University of Texas at San Antonio. Diagnostic and selected artifacts from the survey are illustrated and described here.

Site $41 \mathrm{GZ}$ 162, Projectile point (Fig. 8,a)

Surface collected. Length, 3.5; Width, 1.8; Thickness, 0.51.*

*A11 measurements are in centimeters unless otherwise noted. 

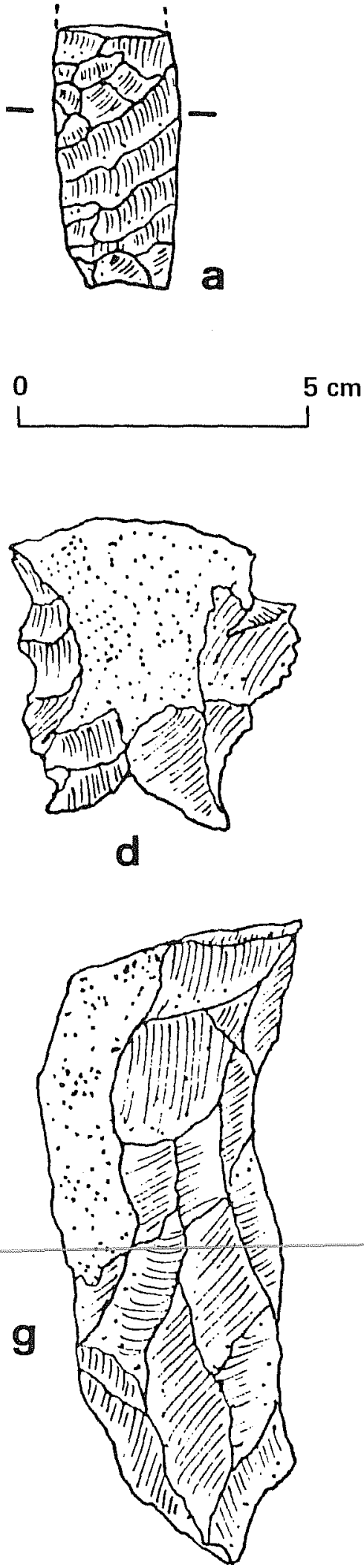




Figure 8. Conquista Survey Artifacts. a, projectile point; b, biface; c, biface fragment; $d$, modified flake; $e$, gouge-like tool; f, biface 
The artifact is lanceolate in shape and is characterized by basal dulling. The base of the point fragment is slightly curved, and the flake scars on the blade reflect long, diagonal flaking. The chert is tan in color and is fire-reddened near the fracture point. The artifact conforms with characteristics of the Paieo-Indian Angostura type as defined by Suhm and Jelks (1962).

Site $41 \mathrm{GZ}$ 162, Biface (Fig. 8,b)

Surface collected. L, 5.9; H, 4.2; T, 1.1 .

The biface is percussion worked and roughly ovate in shape, al though a "beak" has been accidentally or purposefully notched into the biface end. The projection is in part the result of an extensive hinge fracture. The chert is medium brown in color, although it appears fire-reddened in portions.

Site $41 . G 2$ 162, Medial biface fragment (Fig. 8,c)

Surface collected. $L, 2.1 ; W, 2.6 ; T, 0.65$.

The medial fragment is almost translucent neutral in color and is triangular in transverse cross-section. The size of the medial fragment suggests a fragmentary dart point.

Site 41 G7 166, Edge-modified secondary flake (Fig. 8,d)

Surface collected. $L, 4.1 ; \mathrm{W}, 3.9 ; \mathrm{T}, 1.1$.

The secondary flake has been extensively edge-altered by notching along dorsal edges and end. Minute fractures on edges suggest utilization as a casual cutting or scraping too 1.

Site 41 GZ 167, Gouge-like tool (Fig. 8,e)

Surface collected. L, 6.1; W, 4.2; T, 1.2.

The bifacially worked tool is medium brown in color and exhibits a $60^{\circ}$ edge angle along the bit end. Small hinge fractures are evident along the lower end edge.

Site 41 GZ 167, Biface fragment (Fig. 8,f)

Surface collected. L, 5.7; W, 3.8; T, 1.3.

Chert is translucent light brown in color. Thickness and flaking suggest a proximal end of a preform fragment. 
Site 41 GZ 169, Thick biface (Fig. 8,g)

Surface collected. L, $8.4 ; W, 3.4 ; T, 2.7$.

The artifact is medium to dark brown in color and thins along end to a steep bevel. Biface has been marginally retouched on ventral surfaces and shows little wear or utilization.

Site 41 AT 59, Uniface (Fig. 8,h)

Surface collected. L, 7.9; W, 5.5; T, 2.5.

Coarsely grained and of poor quality chert, the artifact is marginally trimmed along the dorsal side and end. Hinge fracturing along end suggests utilization, probably as a scraping tool.

Site 41 AT 61, Metate (Fig. 9)

Surface collected. L, 40; W, 35; T, 10 .

Composed of coarse grained, light-gray sandstone, the metate reflects extensive utilization not only for food preparation but for other activities as well. Numerous grooved straight lines on both sides suggest manufacturing or sharpening activities, as in the production and use of pointed bone tools (awls, perforators, needles).

\section{CONCLUDING COMMENTS AND RECOMMENDATIONS}

Concluding Comments

In the past, archaeological interests within the general area have fallen into two main studies: settlement patterns and 1ithic studies. Hester (1975b) deals with the latter by describing lithic industries of the region. He also (1976) emphasizes several characteristics of prehistoric Archaic sites which are reflected in site locations found during the Conquista survey: (1) the heterogeneity of aboriginal settlement patterns from one drainage to another; (2) the positioning of sites in proximity to several micro-environments; (3) aboriginal intrasite planning; and (4) functional differentiation of sites.

General characteristics of prehistoric interests noted during current survey operations include: (1) a paucity of 1 ithic resources and a dependence on small outcroppings of stream pebbles and gravels exposed by erosions; (2) a preference for translucent, neutral colored chalcedony materials; and (3) occupational and multi-functional sites situated to exploit several resources simultaneously. Vertical distance from the water source had the largest variance when identifying these sites. Most categories of worked stone found throughout the surveyed areas contained various types of chert, silicified wood, and quartzite. No gravel bars were noted at the drainages inspected, and it is assumed that lithic materials were recovered from gravel-bearing terrace systems or from eroding upland ridge system gravel deposits. 


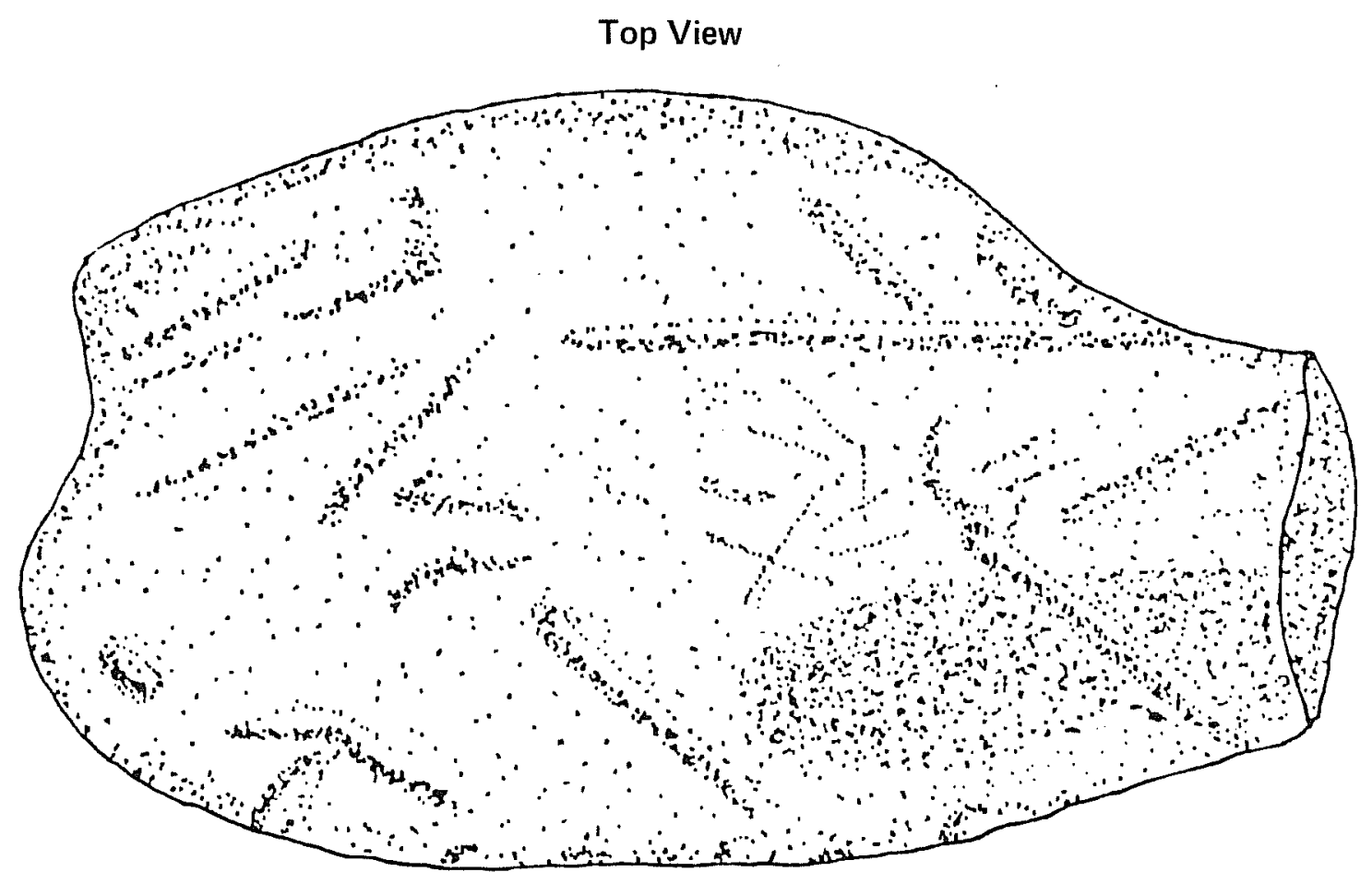

Side View



40 Centimeters

Figure 9. Conquista Survey Artifact. Sandstone metate surface collected from 41 AT 61 . 
Fire-reddened lithic debris was noted among lithic materials throughout the lease area, and it is conceivable that heat treatment of chert and other materials was a part of prehistoric lithic technologies in the area. The scarcity of chronologically diagnostic artifacts in the survey operation precludes judgments on upland and lowland occupational stages, al though it should be noted that the presence of Angostura cultural materials was identified in the general lowland area of site $41 \mathrm{GZ} 162$.

In discussing the archaeology of Gonzales County, Fox et al. (1974) suggest the area generally includes: (1) high numerical density of sites, (2) extensive horizontal occupational zones or areas, and (3) high artifact yields. The latter is not applicable to the 11 new sites recorded during the course of the present survey, although this may be due to previous site damage and past disturbances.

Intersite relationships were not determined due to the (1) prior disturbance, alteration or destruction of many of the identified sites; (2) the absence of culturally diagnostic materials; and (3) the lack of archaeological sites over wide survey areas.

\section{Recommendations}

Two sites found during field operations are recommended for further work: the multi-functiona1, extensively-occupied site $41 \mathrm{GZ} 162$ in the Jacobs lease, Gonzales County, and the buried hearth site 41 LK 226 in Live Oak County. Limited testing at these sites will determine if the identified cultural mateials are of the quality to be recommended to the National Register of Historic Places. Since both localities may be extensive, this report recommends the limited and selective trenching by backhoe to most quickly locate subsurface cultural deposits. The careful use of backhoe trenching has proven to be an effective and efficient evaluative procedure, as demonstrated by its extensive use in the Choke Canyon project (T. R. Hester, personal communication). 


\section{REFERENCES CITED}

Anders, R. B. and E. T. Baker, Jr.

1961 Ground-water Geology of Live Oak County, Texas. USGS Bulletin 6105.

Blair, W. F.

1950 The Biotic Provinces of Texas. Texas Journal of Science 2(1): 93-117.

1952 Mammals of the Tamaulipan Biotic Province in Texas. Texas Journal of Science 4(2):230-250.

Byrd, C.

1971 Origin and History of the Uvalde Gravel of Central Texas. Baylor Geological Studies Bulletin 20.

Campbe11, T. N.

1960 Archeology of the Central and Southern Sections of the Texas Coast. Bulletin of the Texas Archeological Society 29(for 1958): $145-175$.

Crawford, D. D.

1971 An Archeological Reconnaissance of Ecleto Creek Watershed, South Central Texas. Texas Archeological Salvage Project, Survey Report 8.

Creel, D., A. McGraw, F. Valdez and T. Kelly

1979 Excavations at 41 LK 106, A Prehistoric 0ccupation Site in Live Oak County, Texas. Center for Archaeological Research, The University of Texas at San Antonio, Archaeological Survey Report 62.

Fox, D., R. Mallouf, N. O'Malley and W. Sorrow

1974 Archeological Resources of the Proposed Cuero I Reservoir, De Witt and Gonzales Counties, Texas. Texas Historical Commission and Texas State Water Development Board, Archeological Survey Report 12 .

Hester, T. R.

1968a Folsom Points from Southwest Texas. Plains Anthropologist 13(40): 117.

1968b Paleo-Indian Artifacts from Sites along San Miguel Creek. Bulletin of the Texas Archeological Society 39:147-161. 
Hester, T. R. (Con't)

1968c Paleo-Indian Materials from a Site on Oso Creek, Nueces County, Texas. Houston Archaeological Society Newsletter 25:5-8.

1969 The Floyd Morris and Ayala Sites: Discussion and Comparison. Bulletin of the Texas Archeological Society 40:157-166.

1970a Metal Projectile Points from Southern Texas. The Record 27:

9-11. Dallas Archeological Society.

1970b Marine Shells from Archaeological Sites in Southwest Texas. Texas Journal of Science 22:87-88.

1971 Archeological Excavations at the La Jita Site, Uvalde County, Texas. Bulletin of the Texas Archeological Society 42:51-148.

1972a Toltec Artifacts from Southern Texas. Southwest Museum Masterkey 46(4):137-140.

1972b The Evidence for Prehistoric Trade on the Rio Grande Plain. In Archaeological Papers Presented to J. W. House:21-25. Privately printed, Berkeley, California.

1972c The Surface Archaeology of Three Sites in Duval County, Southern Texas. Lower Plains Archeological Society Bulletin 2(1971):45-71.

1975a Chipped Stone Industries on the Rio Grande Plain, Texas: Some Preliminary Observations. Texas Journal of Science 26(1-2):213-222.

1975b Archaeological and Historical Resources in the San Antonio-Guadalupe River Basins: A Preliminary Statement. Center for Archaeological Research, The University of Texas at San Antonio, Regional Studies 1.

Hester, T. R. (editor)

1976 The Texas Archaic: A Symposium. Center for Archaeological Research, The University of Texas at San Antonio, Special Report 2.

Hester, T. R., R. F. Heizer and J. A. Graham

1975 Field Methods in Archaeology, 6th Edition. Mayfield Publishing Company, Palo Alto, California.

Hester, T. R. and T. C. Hi11, Jr.

1971 An Initial Study of a Prehistoric Ceramic Tradition in Southern Texas. Plains Anthropologist 16(53):195-203. 
Hester, T. R. and T. C. Hill, Jr. (Con't)

1975 Some Aspects of Late Prehistoric and Protohistoric Archaeology in Southern Texas. Center for Archaeological Research, The University of Texas at San Antonio, Special Report 1.

Hester, T. R., J. W. House, R. N. Jack and F. H. Stross

1975 X-ray Fluorescence Analysis of Archaeological Obsidian from the Rio Grande Plain, Southern Texas. Texas Journal of Science $26(1-2): 286-289$.

Hester, T. R. and R. W. Rodgers

1971 Additional Data on the Burial Practices of the Brownsville Complex. Texas Journal of Science 22(4):367-372.

Hester, T. R. and F. Ruecking

1969 The Ayala Site. Bulletin of the Texas Archeological Society 40:147-157.

Hester, T. R., L. D. White and J. White

1969 Archaeological Materials from the Oulline Site (4I LS 3) and Other Sites in La Salle County, Southwest Texas. Texas Journal of Science 21(2):131-166.

Hi11, T. C., Jr. and T. R. Hester

1971 Isolated Late Prehistoric and Archaic Components at the Honeymoon Site, Southern Texas. Texas Archeology 17(2):10-14.

Hi11, T. C., Jr., J. W. House and T. R. Hester

1972 Notes on Incised and Grooved Stones from Southern and Western Texas. Lower Plains Archeological Society Bulletin 3:1-10.

Hsu, D. and R. Ralph

1968 An Appraisal of the Archeological Resources of Cibolo Reservoir, Witison county, Texas. Texas state Building Commission and Texas State Water Development Board, Archeological Survey Report 1.

Johnson, L., D. A. Suhm and C. D. Tunnell

1962 Salvage Archaeology of Canyon Reservoir: the Wunderlich, Footbridge and Oblate Sites. Texas Memorial Museum Bulletin 5.

Lynn, W., D. Fox and N. O'Malley

1977 Cultural Resource Survey of Choke Canyon Reservoir. Texas Historical Commission, Archeological Survey Report 20. 
McGraw, A. J. and F. Valdez, Jr.

197841 BX 68: A Prehistoric Quarry-Workshop in Northern Bexar County, Texas. Center for Archaeological Research, The University of Texas at San Antonio, Archaeological Survey Report 56.

McGraw, A. J., F. Valdez, Jr. and W. Cox

1977 Archaeological Survey of Areas Proposed for Modification in the Encino Park Development, Northern Bexar County, Texas. Center for Archaeological Research. The University of Texas at San Antonio, Archaeological Survey Report 39.

Mallouf, M.

1975 Three Rivers Flood Protection Project, Live Oak County, Texas: An Archaeological and Historical Survey of Areas Proposed for Modification. Report to the Fort Worth District Corps of Engineers by the Texas Archeological Survey, The University of Texas at Austin.

Nunley, J.P.

1963 Appraisal of the Archaeological Resources of Columbus Bend Reservoir, Colorado and Fayette Counties, Texas. Report submitted to the National Park Service by the Texas Archeological Salvage Project, Austin.

Nunley, P. and T. R. Hester

1966 Preliminary Archaeological Investigations in Dimmit County, Texas. Texas Journal of Science 18(3):223-253.

Redman, C. L..

1974 Archaeological Sampling Strategies. Addison-Wesley Module in Anthropology 55.

Shafer, H. J. and E. P. Baxter

1975 An Archaeological Survey of the Lignite Project, Atascosa and McMullen Counties, Texas. Anthropology Laboratory Report 7,

Texas A\&M University.

Shafer, H. J. and T. R. Hester

1971 A Study of the Function and Technology of Certain Bifacial Tools from Southern Texas. Texas Historical Commission, Office of the State Archeologist, Report 20. 
Smith, H.

1978 Archaeological Survey and Assessment of Properties for the Conquista Project in Live Oak and Karnes Counties, Texas. Center for Archaeological Research. The University of Texas at San Antonio, Archaeological Survey Report 64.

Suhm, D. A.

1960 A Review of Central Texas Archeology. Bulletin of the Texas Archeological Society 29(for 1958):63-107.

Suhm, D. A. and E. B. Jelks (editors)

1962 Handbook of Texas Archeology: Type Descriptions. Texas Archeological Society, Special Publication 1, and Texas Memorial Museum, Bulletin 4 .

United States Department of the Interior

1975 Final Environmental Impact Statement, Nueces River Project, Choke Canyon Dam and Reservoir Site, Texas. Bureau of Reclamation, Southwest Region, Amarillo.

Wakefield, W. H.

1968 Archeological Surveys of Palmetto Bend and Choke Canyon Reservoirs, Texas. Texas Archeological Salvage Project, Survey Report 5.

Wilson, A. M.

1930 Areal Survey of Bastrop and Fayette Counties. Manuscript on file at the Texas Archeological Research Laboratory, The University of Texas at Austin. 